\title{
THE VALUES OF BATANG HARING AS LOCAL WISDOM IN BUILD ING THE SUSTAINABLE COMPETITIVE ADVANTAGE OF TOURISM DESTINATION IN CENTRAL KALIMANTAN
}

\author{
${ }^{1}$ Daniel Pandu Mau, ${ }^{1}$ Tjokorda Gde Raka Sukawati \\ ${ }^{1}$ Department of Hotel and Tourism Management, Bali International Polytechnic, \\ Indonesia. \\ ${ }^{2}$ Faculty of Economics and Business, University of Udayana, Indonesia. \\ daniel_pandumau_ilj@rocketmail.com
}

\begin{abstract}
As a regional tourism destination in Indonesia, Central Kalimantan has cultural richness from its sub-ethnics of Dayak (indigenous people in Kalimantan) that can be used to develop its tourism products. Therefore, through an ethnographic approach using triangulation data collection techniques, this study explored, illustrated and comprehended in-depth the culture of Central Kalimantan specifically local wisdom values. Batang Haring as a local wisdom of Dayak in Kalimantan, particularly Central Kalimantan, has culture value that is the balanced and harmonious relationship among three-dimensional: human, God, and nature implemented through rites of Kaharingan (traditional belief of Dayak). The uniqueness in implementing the values become a "spirit" that is able to "awaken" and more "revive" Central Kalimantan, specifically in tourism sector. The strongly formed "spirit" will be a basic strength of differentiation strategy to create different, unique and unimitate products as a factor of competitive advantage in its tourism products. Utilization of these values can be done through cultural practices, DayakKaharingan rite activities, and the use of cultural symbols in its development. However, it needs to be applied consistently in everyday life and supported through the hospitality of its people who live spiritually and continue to uphold their culture and arts that will form a strong "spirit" and hard to find elsewhere. Thus, the tourism sector can be sustainable and will impact on strengthen economic activity, as well as improve the living standard of its community as host.
\end{abstract}

Keywords: Batang Haring, Dayak-Kaharingan, Local Wisdom Values, Competitive Advantage

\section{INTRODUCTION}

Globally, tourism as an economic activity is important for many countries that try to obtain a share of this estimated $\$ 7.6$ trillion industry (WTTC, 2015). It can create job, bring wealth and economic benefits for those nations and their regions. Thus, it is probably the single most important industry in the world (Charles and 
Tian, 2011; Kalaiya, 2015; Holloway and Humphreys, 2016; UNWTO, 2017). Along with the rapid development of the global tourism sector, triggering various destinations to increase their competitiveness. Besides, the competition among destinations in attracting and engaging tourists to visit has been increased as well, likewise tourism destinations in Indonesia that have been increasingly competing to develop their potentials. However, not all of these destinations are able to manage optimally their potentials owned. Likewise, region of Central Kalimantan that is actually rich in unspoiled tourism potentials that are unique and different from other destinations, particularly in the aspect of culture from various sub-ethnics of Dayak (indigenous people in Kalimantan). In fact, these potentials can be managed optimally to build its competitive advantage even sustainably, especially in its tourism product. Therefore, it can be able to compete with other destinations in attracting more tourists to visit optimally.

In general, competitive advantage is a strategy to help a company to improve its performance in order to produce high profits and maintain its survival amid increasingly fierce competitions (Day and Wensley, 1988). Moreover, it will determine a company's ability to create and maintain superior values sustainably (Barney and Clark, 2007). Competitive advantage is an ability to achieve economic benefits over the profits achieved by competitors in a same market industry (Porter, 1986). Besides, a company that has competitive advantages always has an ability to comprehend changes in market structure and able to choose effective marketing strategy (Peters and Waterman, 1982). The study conducted by Porter (1996) further establishes generic strategies to build the competitive advantage classified in three categories, namely: cost leadership, differentiation, and focus.

Differentiation is a generic strategy that is generally accepted in market competition (Porter, 1986; Bharadwaj et al., 1993) to create uniquely desirable products and services. The success indicator of this strategy is being able to produce customer and perceive value that are recognized and accepted. The success key is in the effort to develop "point of differentiation" that is not easily copied, especially from the customer's point of view rather than company's operations. However, the point of differentiation must be sustainable.

Sustainable competitive advantage based on differentiation can be formed by using the uniqueness of resources owned that is difficult to imitate (Porter, 1985). Therefore, these advantages can be built by combining the unique elements of the resources and competencies of the company, or known as Resource-Based View (RBV) (Barney, 1991). The RBV will describe, explain, and predict how company can achieve these advantages through the use and control of unique resources that cannot be imitated by competitors (Barney, 1991; Peteraf, 1993; Hunt, 2000).

The unique resources of a company can be drawn from culture that exists in its company. Cultural characteristics, that are valuable, rare, inimitable, and nonsubstitutable (VRIN), can be a source of competitive advantage. The strong cultural values will encourage creativity and innovation so it can contribute to the company's competitive advantage (Deal and Kennedy 1982; Peter and Waterman, 1982; Tichy, 1983; Kotter and Heskett, 1992; Quick, 1992; Freiberg and Freiberg, 1996; Collins and Poras, 1996; Sukawati, 2014).

Local wisdom is a part of cultural (Brata, 2016) as an original knowledge of a community that comes from the noble value of local culture traditions to regulate the order of people's live wisely (Sibarani, 2012). The values of local wisdom can 
be used as a source of differentiation strategy (Bendesa, 2010) that has been proven to be able to create a variety of uniqueness that make a difference from competitors' products (Sukawati, 2014). In tourism industry, using the uniqueness of local wisdom in the development of differentiation can be done through products that will be able to make its existence survive and sustainable. In general, differentiation in terms of product that is "striking" will be able to stimulate consumers' memory, for it will be appreciated intellectually (Trout, 2001). Thus, the differences can be the basis in influencing consumers to choose product among many bids on market, both implicitly and explicitly.

In the context of tourism, uniqueness can be developed through "inculcating" the values of local wisdom as a "spirit" in its development (Sukawati, 2014). It will be able to create differentiation products than other destinations. Therefore, it must be maintained to lead to sustainable tourism. The local wisdom has potential as a basis for creative economy and sustainable capital (sustainability), so it needs to be explored more (Geriya, 2011).

This study aimed to design a strategy that can be used to build competitive advantage of tourism destination in Central Kalimantan, namely using the strategy of differentiation adopted from one of the Porter's generic strategies $(1980 ; 1986)$. Using an ethnographic approach, this study explored, described and interpreted indepth its cultural richness. It aimed to provide a comprehensive pictures and interpretation of its community from the indigenous' point of view (emic), specifically the values of Batang Haring as a local wisdom of Dayak to be used as a basic strength for creating differentiation of its tourism products. The differentiation based on the local wisdom values that has uniqueness can build a sustainable competitive advantage of tourism destination even sustainably.

\section{METHODOLOGY}

This research was an ethnographic study to explore the values of local wisdom which described and interpreted from aspects of culture, social group or system. However, it focused only on patterns of activity, language, belief, rituals, and ways of life of a community. The data were collected through triangulation techniques, namely 1) interview (semi-structured, deep and natural, and informal setting), 2) observation (participatory, forthright and disguised), and 3) document record study. These data were sourced from social situations that were located in Central Kalimantan through local wisdom activities performed by local actors.

The research process started from collecting data, interviewing informants, making ethnographic records, analyzing the results of interviews, making component analysis, finding cultural themes, and making ethnographic. The key informant in this study was an historian and traditional figure who mastered the cultural of Central Kalimantan. The references and meanings revealed from the key informant determined the guidelines for the next informants. Additional informants continued until the data was saturated. In addition, the researcher acted as the main informant because the researcher is an indigenous of Central Kalimantan who was born and lives in it, as well has studied and applied the values of local wisdom to the present.

Data was obtained as well from secondary sources as proponent that had been processed and compiled from various sources, as well form literature or 
bibliography that support related to the research problems. Data collected in the form of ethnographic records from informants were analyzed using four stages, namely ethnographic interview analysis, domain analysis, taxonomic analysis, and component analysis. The last stage of this research was conducting data credibility tests that aimed to assess the truth of research findings performed by 1) extending the observation, 2) increasing the perseverance, 3) re-conducting the triangulation, 4) using reference material as support for data found related to the research, and 5) holding a member check.

\section{RESULTS AND DISCUSSIONS \\ a) Batang Haring as a Local Wisdom of Central Kalimantan}

Literally, Batang Haring comes from the language of Sangiang (ancient language of Dayak ethnic) and written in Panaturan (religious scripture of HinduKaharingan) means the tree of life (batang $=$ tree and haring = life). As in the philosophy of Tri Hita Karana (basic concept of Balinese Hinduism), it describes as well as a balanced and harmonious relationship of three dimensions (human, God and nature) as a source of peace in life. The tree of life has three branches that symbolize three appreciations as a guidelines of life (haring hatungku tungket langit), namely: (1) kayu gambalang nyahu (the relationship between human and God) which means humans are religious and believe in God Almighty One, (2) kayu pampang seribu (the relationship between human and fellow humans), which means humans as social beings who maintain cultural customs and etiquette, and (3) kayu erang tingang (the relationship between human and nature), which means humans need to learn a lot about science from their natural environment. As a local wisdom, Batang Haring is interpreted as a basis and purpose of life for Dayak ethnic in Central Kalimantan. The form of a balanced and harmonious relationship of the three dimensions can be described as follows:

\section{Figure 1. Batang Haring}

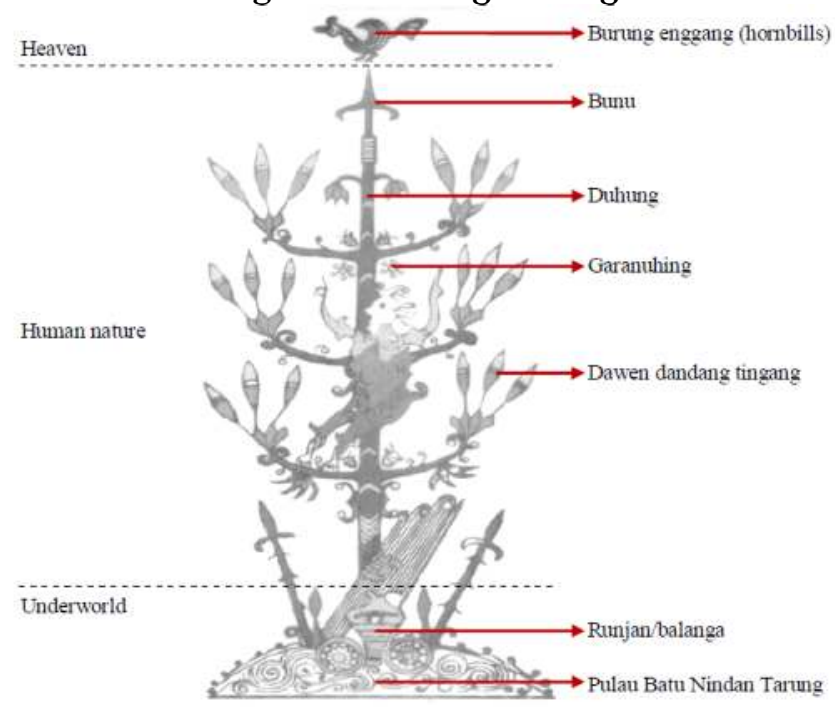

Source: Sangalang et al. (1997)

The elements contained in Batang Haring symbolize human life itself. Figure 1 illustrates the three dimensions of life, namely: heaven, human nature, and underworld. At the very top symbolized by Tingang/Enggang (Hornbill) as a 
symbol of God's power. At the very bottom symbolized by runjan/balanga (urn) is the underworld controlled by Jata / Tambun (dragon) as the God's shadow. In the middle, human nature, describes everything that is related to human life in the world.

If Batang Haring is related to the philosophy of community life of DayakCentral Kalimantan, then heaven and underworld connected by duhung describes the relationship between human and God (kayu gambalang nyahu), human nature describes the relationship between human and fellow humans (kayu pampang seribu), while the relationship between human and nature (kayu erang tingang) described by runjan/balanga. The meaning of each symbol part shown in Figure 1 can be seen in the following Table 1.

Table 1. The Meaning of Symbols in Batang Haring

\begin{tabular}{|c|c|c|}
\hline $\begin{array}{l}\text { Parts of } \\
\text { Symbol }\end{array}$ & Meaning & Divisions from Symbol \\
\hline $\begin{array}{l}\text { Burung } \\
\text { Enggang } \\
\text { (Hornbills) }\end{array}$ & $\begin{array}{l}\text { Real life is originated from above } \\
\text { (heaven). }\end{array}$ & Heaven. \\
\hline Вunu & $\begin{array}{l}\text { Humans only serve God. Thus, all } \\
\text { their behavior must be in } \\
\text { accordance with God's will. }\end{array}$ & $\begin{array}{l}\text { Human nature: the } \\
\text { relationship between } \\
\text { human and God (kayu } \\
\text { gambalang nyahu). }\end{array}$ \\
\hline Duhung & $\begin{array}{l}\text { Existence of the spear is to connect } \\
\text { between the top and bottom which } \\
\text { symbolizes the heaven and } \\
\text { underworld are one and } \\
\text { interconnect. }\end{array}$ & $\begin{array}{l}\text { Human nature: the } \\
\text { relationship between } \\
\text { human and God (kayu } \\
\text { gambalang nyahu). }\end{array}$ \\
\hline Garanuhing & $\begin{array}{l}\text { Humans must direct their gaze, not } \\
\text { only downward but also upward. } \\
\text { That is, humans must respect } \\
\text { Ranying Hatalla Langit (God) and } \\
\text { Jata/Tambun (God's shadow) in } \\
\text { balanced. Another understanding, } \\
\text { humans must be able to maintain } \\
\text { balance between worldly interests } \\
\text { and the hereafter. }\end{array}$ & $\begin{array}{l}\text { Human nature: the } \\
\text { relationship between } \\
\text { human and God (kayu } \\
\text { gambalang nyahu). }\end{array}$ \\
\hline $\begin{array}{l}\text { Dawen } \\
\text { dandand } \\
\text { tingang }\end{array}$ & $\begin{array}{l}\text { Humans must have patience in } \\
\text { dealing with their life. } \\
\text { Humans must be able to control } \\
\text { themselves, so they are not } \\
\text { misdirected. } \\
\text { Humans must be able to protect and } \\
\text { preserve nature. }\end{array}$ & $\begin{array}{l}\text { Human nature: the } \\
\text { relationship between } \\
\text { human and God, the } \\
\text { relationship between } \\
\text { human and fellow } \\
\text { humans, and the } \\
\text { relationship between } \\
\text { human and nature. }\end{array}$ \\
\hline $\begin{array}{l}\text { Runjan/ } \\
\text { balanga } \\
\text { (urn) }\end{array}$ & $\begin{array}{l}\text { Wealth and prosperity given by } \\
\text { God. }\end{array}$ & $\begin{array}{l}\text { Underworld: the } \\
\text { relationship between } \\
\text { human and nature (kayu } \\
\text { erang tingang). }\end{array}$ \\
\hline
\end{tabular}




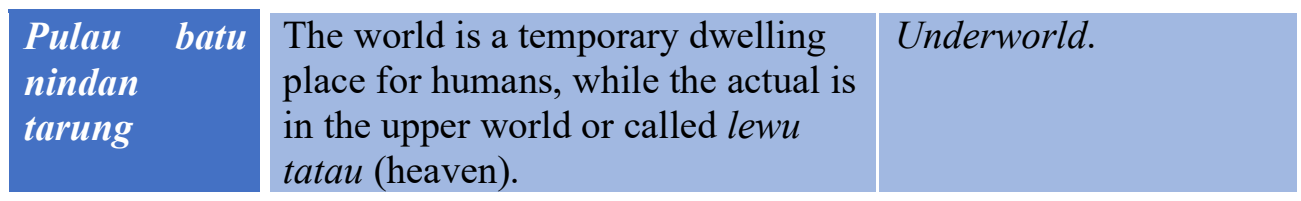

Source: Adopted from Sangalang et al. (1997)

The symbols in Batang Haring have a unity that is bound together. That is, to be able to create a balanced and harmonious relationship as a source of peace in life, both microcosmically and macrocosmically, need to maintain the threedimensional relationships among human, God, and nature. Besides, there are five surrenders (Lime Sarahan) implied in Batang Haring, namely: Hatala Katamparan (the creator of all creations), Langit Katambuan (the sky above humans head), Petak Tapa Jakan (the land where humans stand), Nyalung Kapandoyan (the holy water as a purifier for humanself), and Kalata Padadokan (the universe where humans can live). Lime Sarahan always becomes prayer in every traditional ceremony, as well before carrying out their daily activities. It is intended that humans are always aware of their life origin and purpose.

\section{b) Implementation of Batang Haring Values: Awaken the "Spirit" of Tourism Destination in Central Kalimantan}

The real action shows the balanced and harmonious relationship among the three-dimensional relationships in Batang Haring can be seen from the daily activities of the community in Central Kalimantan, in the form of relationship with God, fellow humans, and natural environment. The results of the domain, taxonomy and component analysis, associated with cultural theories of Schein (2004) and Koentjaraningrat (2005), have a view that a culture consist of artifacts or material system related to kayu erang tingang, espoused values or social system related to kayu pampang seribu, and basic underlying assumption or value system related to kayu gambalang nyahu. The relationship between cultural and Batang Haring that have been performed in Central Kalimantan can be illustrated in Table 2 below:

Table 2

The Matrix of Relationship between Batang Haring and Cultural

\begin{tabular}{|c|c|c|c|}
\hline $\begin{array}{l}\text { Batang Haring/ } \\
\text { Schein and } \\
\text { Koentjaraningrat }\end{array}$ & $\begin{array}{c}\text { Kayu } \\
\text { Gambalang } \\
\text { Nyahu }\end{array}$ & $\begin{array}{c}\text { Kayu Pampang } \\
\text { Seribu }\end{array}$ & $\begin{array}{c}\text { Kayu Erang } \\
\text { Tingang }\end{array}$ \\
\hline $\begin{array}{l}\text { Basic underlying } \\
\text { assumption or } \\
\text { value system }\end{array}$ & Belief & $\begin{array}{l}\text { 1. Paleteng } \\
\text { Kalangkang } \\
\text { Sawang } \\
\text { 2. Maruah Awau } \\
\text { 3. Nahunan } \\
\text { 4. Balian } \\
\text { Mampandui } \\
\text { Awau } \\
\text { 5. Tiwah/Wara/ } \\
\text { Jambe } \\
\text { 6. Etc. }\end{array}$ & $\begin{array}{l}\text { 1. Mampakanan } \\
\text { Sahur } \\
\text { 2. Mamapas } \\
\text { Lewu/Sedekah } \\
\text { Bumi } \\
\text { 3. Manyanggar/ } \\
\text { Manejep Petak } \\
\text { 4. Etc. }\end{array}$ \\
\hline $\begin{array}{l}\text { Espoused values } \\
\text { or social system }\end{array}$ & $\begin{array}{l}\text { 1. Pantan } \\
\text { Balanga }\end{array}$ & 1. Kedamangan & Handel \\
\hline
\end{tabular}




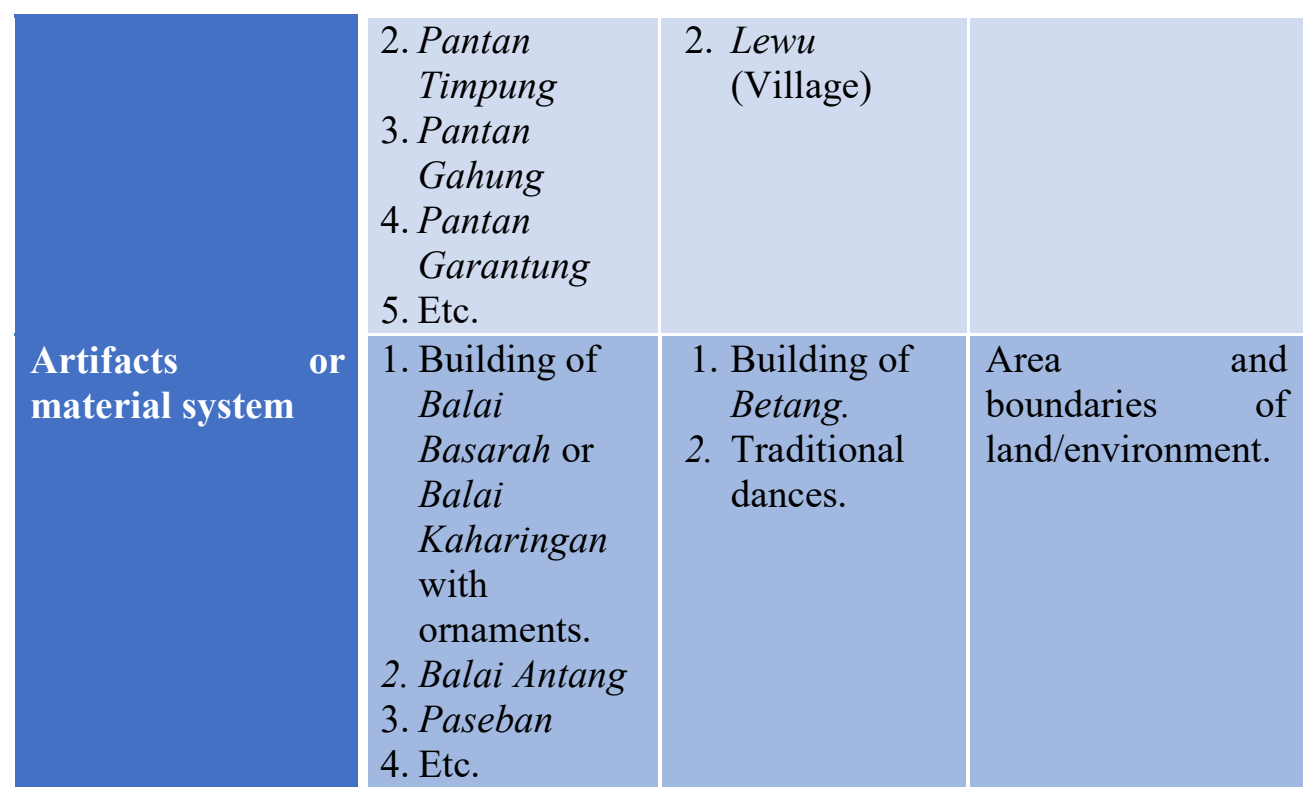

Table 2 explained that the community of Central Kalimantan implements the culture related to God (kayu gambalang nyahu) based on their respective beliefs, such as in Kaharingan (traditional belief of Dayak) performed through the activities of Dayak-Kaharingan rites, which is making offerings sincerely by taking place in Balai Basarah, Balai Antang, and other sacred places. In establishing the harmonious relationship with God, those activities encourage a creation of learning and arts, as well producing spiritual respect for maintaining a relationship with God. The power of encouragement that comes from the values of belief makes an activity has internal strength in maintaining a harmonious relationship with God. Besides, through the rites of Dayak-Kaharingan builds up the creativity in arts and its implementation, as well the social interaction in community goes on harmoniously.

The strength in maintaining the relationship with God gives a different touch in the order to perform devotion to God. That is, it will become an attraction for others to see and deepen it. The interest arisen means there is a hidden value that cannot be felt anywhere else. Therefore, this concept can be one of the tools to attract customers in marketing. The differentiation can be used as a "weapon" to perform a strategy in product marketing, which is known as the concept of differentiation strategy (Barney and Clarke, 2007). The difference in performing activities is an asset for a company by viewing it as something to be thankful for. Through these differences, the harmony can be created because of the awareness of having weakness. For this reason, looking at humans is the same as serving God (Sukawati, 2014).

The concept of kayu pampang seribu (balanced and harmonious relationship between human and fellow humans) is a belief in humans that there is a power of God. Through this awareness, various kinds of rituals are performed such as in Kaharingan. Moreover, it must be supported by a good social system to make it success, such as through groups, kedamangan, or lewu (villages) where the humans live. Certainly, these activities require a physical place in the form of buildings or other artifacts. Known as a communal society, all activities carried out by communal efforts, not individual. Someone is considered as an inseparable part of 
the community whether at family or village community level. This harmonious relationship known as a culture/ tradition of Betang which encompasses four pillars, namely value of togetherness/ mutual cooperation, honesty, equality, and tolerance.

Through the activities of community of Central Kalimantan in performing sincere relationships between fellow humans produces a very unique art as a part of culture. Therefore, from the component analysis it can be said that "the cultural of Central Kalimantan which has "spirit" will bring up innovative and competitive art products". This condition will be in line with the strategy of Barney and Clarke (2007).

The concept of kayu erang tingang (balanced and harmonious relationship between human and nature) will bring up the value of belief that nature also has its inhabitants. Thus, it is necessary to offer sincerely through various rituals, such as in Kaharingan, namely mampakanan sahur, mamapas lewu, manyanggar, and other rituals. The rituals are performed if the nature will be used which for thousands of years initially made itself sustainable and then became built according to human's will as a place to live. The sustainable of nature is a form of God's gift to humans to be used as a place of prosperous and happy life. As a sign or symbol of thanks to nature, usually the buffalo / cow's head is implanted by the community. It is performed as a form of agreement that the nature is not destroyed in vain yet used with good intentions in accordance with the will of God Almighty.

Various kinds of rituals in the concept of kayu erang tingang are also performed to avoid bad conditions and to keep maintain contact with spiritual centers, sacred and holy places. Moreover, through these rituals also can form a "strong fence" and built "goldthread" as a controller of the centers of spiritual power in question. Related to nature, the concept of kayu erang tingang will bring up social system rules in relation to land use, such as handel system used in managing and utilizing the land. This concept will bring up land boundaries and stakes.

The fundamental difference in the concept of modern marketing is more emphasis on relationship pattern of creating consumer value based on professional relationships. It is highly commercial based on how much benefit the consumer receives from the costs spent. However, marketing based on local wisdom more emphasizes on traditional patterns of relationships based on the consistency of three-dimensional relationships among humans, God and their natural environment. It is implemented in cultural relations and reflected in the relationship patterns of value systems, social systems and artifacts.

Related to the context of tourism in Central Kalimantan, the relationship model between the local wisdom values and culture in building a sustainable competitive advantage will be reflected in the pattern of relationships between the value system and kayu gambalang nyahu, including the belief implemented in daily life of its community. The relationship between the value system and kayu pampang seribu reflected through ritual activities of Dayak-Kaharingan rites, such as nahunan, tiwah, and other rituals, either large or small scale that have a very deep spiritual meaning and must be run consistently. The relationship between the value system and kayu erang tingang reflected in the form of ritual activities in respecting nature, such as mampakanan sahur and mamapas lewu performed in Kaharingan. The relationship pattern of Batang Haring and cultural in Table 2 is an important elements to build competitive advantage for sustainable tourism in Central 
Kalimantan. The balance in implementing modern marketing concepts based on local wisdom will be an important element in maintaining and building competitiveness of tourism industry.

Based on the previous explanations related to the implementation of Batang Haring by putting forward the concept of balanced and harmonious relationship among human, God, natural environment, then a minor preposition can be raised that "the implementation of Batang Haring performed sincerely and spiritually will rise up the "spirit" that will make Central Kalimantan more "reviving".

\section{c) Implementing the Concept of Batang Haring through the Rites of Dayak- Kaharingan}

The rite of Dayak-Kaharingan is one of the real acts in implementing the concept of Batang Haring illustrates the balanced and harmonious relationship among humans, God, and nature. Various rituals of the rite started from ritual of birth, life, death, even after death in the form of offerings to God and ancestors based on sincerity. One of the rituals is tiwah as the biggest ritual in the community of Dayak-Central Kalimantan. It is a ritual of death (Pitra Yadnya) as a demand of sacred obligations as well as an implementation of faith in Kaharingan. Tiwah is a continuation procession (secondary funeral), which usually takes place several months or sometimes years after initial burial or ordinary death ritual that exhumes and cleans the bones of ancestor who has died and then placed in sandung (a special grave or new tomb container). The aim is to take spirit of the ancestor to the highest point in heaven or land of the spirits called Lewu Tatau Habaran Bulau, Habusung Hintan, Hakarangan Lamiang means a place that is rich and beautiful, as well rich in gold, diamonds and merjan stones.

Ritual of tiwah is a form of worship to God, because nature and its contents created and sourced from God. Ancestors are believed as manifestation of God. Thus, worship to the ancestors is an expression of gratitude for the gifts that have been given to humans by God. In implementing the ritual, it involves a large number of people from various circles who work together voluntarily to help everything related to the ritual activities. Nowadays, the concept of mutual cooperation is rarely found as expressed by Jensen and Meckling (1976) that humans are always opportunistic and materialistic in their actions. Unlike the community of DayakCentral Kalimantan who are happy and proud to participate in the ritual procession regardless of race. In addition, ritual of tiwah contains of harmonization between humans and natural environment. It is an evident as a form of environmental preservation performed by the community through the secondary burial which indirectly minimizes the use of grave land which can cause over capacity in the long term. Besides, the ritual instruments used are local, natural, and recycled materials, so it can be reunited with nature after used. Although the woods used are obtained through the felling of forest trees, yet it will be replaced by replanting the tree in its place. Surely, these activities are performed through certain rituals and conditions before.

In the implementation of Dayak-Kaharingan rites, the ritual instruments used are full of God's symbols, and it has artistic values. Based on taxonomic analysis, it was revealed that through the rite activities in Dayak-Kaharingan would be able to make itself different from other ethnic communities. Moreover, it is able to bring up artists, God's symbols, shady language and sincerity. The rite of Dayak- 
Kaharingan also raises worship places, such as Balai Basarah. It created by artists, contains the symbols of God that provides coolness for those who make prayers. Besides, in the implementation also inseparable with traditional dances in addition to entertainment as well as offerings to God.

As a tourism destination, Central Kalimantan actually holds various pearls as source of competitive advantage in particular the rites of Dayak-Kaharingan that cannot be separated from the local wisdom since it has long been developing in the traditions of its community's life. The rites certainly have a spiritual feel that is different in other regions. However, in the implementation, it needs to take notice well on the elements of arts, and not just a routine ritual that emphasizes on the spiritual imperatives that must be performed. In implementing the rites through each process always accommodates elements of arts. Thus, it will become a landmark of Central Kalimantan, so that each element of the ritual not only looks beautiful and attractive but also gives a sense of pleasure and peace.

The uniqueness in the process of performing the rite of Dayak-Kaharingan in particular tiwah can be a special attraction for tourists. Its own uniqueness can become a cultural tourism icon that has a social economic value attraction. Not only for the various artifacts of tiwah products but also in the process of making various instruments used, which will be the main attraction for tourists who visit. Seeing the ritual and observing the process that are full of nuances of arts and beauty will be able to provide calm and peace for tourists who come and see. Thus, it is expected to lead to tourist satisfaction with the uniqueness of Dayak-Central Kalimantan culture that will never be found in their home regions. Certainly, in each process must not be separated from harmonious cooperation of the local community which is performed sincerely and unconditionally. Another important thing is the packaging aspect. Unique product packaging will affect the attractiveness of consumers. Such product packaging will become a "salesman" that automatically becomes an attraction and at the same time increases the selling value of a product. The packaging of a destination's tourism product is one of the most influencing elements of tourist interest.

Thus, the uniqueness in implementing cultural tourism based on DayakKaharingan rites as local wisdom in Central Kalimantan will make it different from other tourist destinations. Through the differentiation strategy will enable Central Kalimantan to create and maintain its competitive advantage even sustainably. Theoretically, it will be in line with Porter's (1986) theoretical study states that differentiation strategy can be an option for creating competitive advantage, in addition to a low-cost and focused strategy. It also supports the theoretical study of Barney and Clarke (2007) which states that the source of sustainable competitive advantage is caused by the ability of a corporate organization to create unique resources that are not easily imitated, scarce, and cannot be transferred easily.

Based on the previous explanations, a minor preposition can be made that "the rite activities of Dayak-Kaharingan is a value system that has uniqueness in creating the "spirit" of Central Kalimantan".

d) The "Spirit" of Batang Haring Implemented through the DayakKaharingan Rites Activities as Local Wisdoms Creates Uniqueness

Spirit is a non-material element in the "body" created by God as cause of a life. In the belief of Kaharingan, its adherents believe that a certain object can have 
an unseen factor of excellent (niskala) compared to other similar objects. It can be in the form of paintings, dances, buildings, places, objects that have certain symbols, and other forms. These powerful and spiritual objects are believed to possess the "spirit".

The excellent factor that has a "spirit" is able to make an object has "soul" to be more "alive" and able to attract many people. However, it does not happen by itself since a process is very important and will determine the final result. A process that is based on good intentions and performed with a positive spirit will surely produce good results. It is that ultimately produces a "spirit" in an object.

Tourism in Central Kalimantan will take place sustainable if it has a "spirit" with always taking notice on the process and final results. Spiritual, social and environmental aspects must work in balance and harmony so that a better life is achieved. Through this philosophy, it will be able to rise up a strong "spirit" that will distinguish the destination from other regions and make tourists never get bored visiting. The "spirit" will not be formed by itself but built from the local wisdom that has been owned for centuries, and applied consistently in everyday life. Certainly, it needs to be supported by hospitality of its community who live spiritually and continue to uphold their cultures and arts, and then it will form a strong "spirit" of Central Kalimantan. The "spirit" that was born due to the hard work and wisdom of the ancestors needs to continue to be performed by the entire community. Through the strong character of its nature, culture and society of Central Kalimantan will become uniqueness that is hard to find its equivalent elsewhere, certainly by continuing to maintain the "spirit" in the midst of increasingly rapid changes so that it will continue to be sustainable.

The implementation of Batang Haring through the Dayak-Kaharingan rites activities in social interactions cannot be separated from Central Kalimantan for it can produce different vibration, both by nature and society. Therefore, the difference that becomes "spirit" will not be easily imitated because formed through a process that is quite unique and adaptive and intangible. The "spirit" will not only produce an overall tourist attraction, yet it will make difference in implementing the modern marketing management principles that more dominated by rational behavior, and based on the concept of consumer behavior theory in generating consumer satisfaction.

Existence of the "spirit" in building the tourism competitiveness of Central Kalimantan will make difference to the implementation of marketing principles based on the local wisdom model. The model of customer satisfaction in the concept of modern marketing is oriented only to consumers, such as: owners or shareholders, employees or staff and consumers themselves. Meanwhile, consumer satisfaction on the marketing models based on local wisdom will exceed customer satisfaction on the concept of modern marketing theory, such as: the existence of religious rituals or beliefs that produce a sense of satisfaction for each individual around, community leaders and organization.

The modern marketing orientation model is centered on understanding needs and desires of consumers, but the marketing model based on local wisdom does not merely understand the needs and desires of consumers, but more broadly, including satisfaction of God in the form of devotion through religious or beliefs ritual processes. The modern marketing orientation ignores elements of nature, but the 
marketing orientation model based on local wisdom gives attention and appreciation to the nature through certain rituals.

The "spirit" will create work of arts and cultures to be different. In the modern marketing, it is an asset that can be used as a competitive strategy. Barney and Clarke (2007) use a uniqueness or differentiation in carrying out a competitive strategy towards sustainable competitive advantage. The concept of customer satisfaction in local wisdom-based marketing model contains the synergy and harmonization of the three-dimensional relationships among human, God and nature. Therefore, from this reason a minor preposition can be made that "the uniqueness of local wisdom "raises" the attractions towards sustainable tourism competitive advantage".

\section{e) Model of Sustainable Competitive Advantage Based on Local Wisdom}

The uniqueness in implementing values of local wisdom will not only be able to create differentiation with other regions or destinations, yet it will also become an attraction for tourists since it creates a strong impression of cultural heritage preservation that is full of peace. Certainly, it needs to be synergized properly and optimally as well performed wisely.

The rites of Dayak-Kaharingan which is performed in a sincere and harmonious way of the relationship between human and God, human and fellow humans, and human with their natural environment in the concept of Batang Haring will be the "basic joints" of differentiation strategy that impact on sustainable competitive advantage of tourism destination in Central Kalimantan.

The difference between Central Kalimantan and other regional destinations will be built through the "spirit" which is based on Batang Haring values implemented through the rites of Dayak-Kaharingan. Therefore, it will be able to make it survive and compete with other destinations, so it can be said that Central Kalimantan has a sustainable competitive advantage (Barney and Clark, 2007). The results of this study can be formed a model of sustainable competitive advantage based on local wisdom as Figure 2.

Figure 2

\section{The Model of Sustainable Competitive Advantage Based on Local Wisdom}
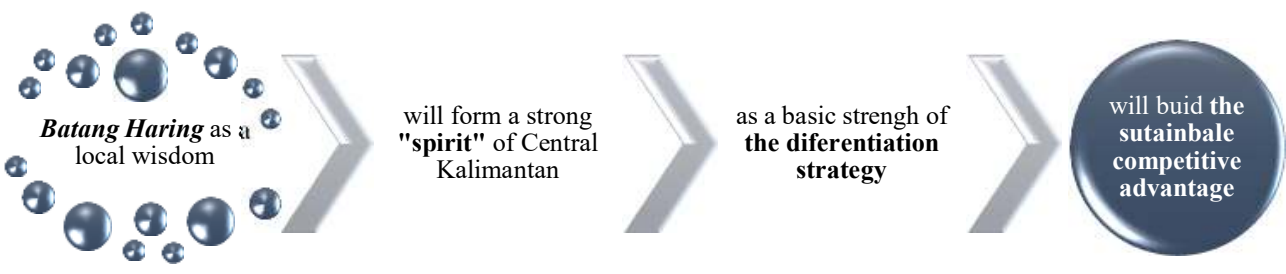

implemented

through Dayak-

Kaharingan rites activites

Figure 2 illustrates a model of sustainable competitive advantage of tourism destination based on local wisdom values built through differentiation strategy. It can be implemented in Central Kalimantan that has different potentials with other regions seen from the various artifacts owned, such as balai basarah, balai antang, balai/ pasah patahu, balai karamai, sandung, sapundu, balanga, batang haring, talawang, betang, traditional dances, and other artifacts. The difference will be 
seen through the implementation of local wisdom values of Batang Haring in the form of Dayak-Kaharingan rites activities that will make all these artifacts have a "spirit" and "come alive". The competitive development model through the implementation of local culture can be a further development of Barney and Clarke's development model (2007) specifically in tourism sector. Thus, the results of previous preposition excavations can be made a major preposition that "the balance and harmony of Batang Haring and the Dayak-Kaharingan rites activities will create a concept of sincere marketing as a source of sustainable competitive advantage".

\section{CONCLUSIONS AND SUGGESTIONS}

The values of Batang Haring as a philosophy of balanced and harmonious relationship of three-dimensional (human, God and nature) can be used as a basic concept in any aspects of developing Central Kalimantan, particularly its tourism sector. It can be implemented through the use of cultural symbols or elements in its product development, or the use of Dayak-Kaharingan rites known as a culture that contains values of Batang Haring as cultural-based tourism attraction products, such as ritual of tiwah. Utilization of these values will form the strong characteristic and identity that makes Central Kalimantan different from other regional destinations. Consistency in implementing the values sincerely will be able to build a competitive advantage even sustainably. However, it is not only in the aspect of development, but also in the daily life activities of the community. In addition, aspect of packaging must be considered that the products are feasible to "sell" and be able to attract tourists to "buy". Certainly, it must be supported through the hospitality of its community who live spiritually and continue to uphold their culture and arts as a form of cultural preservation, so that the tourism sector can be sustainable.

The uniqueness in implementing the values of Batang Haring will be a "spirit" that awakens the "soul" of Central Kalimantan more "reviving". The strongly formed "spirit" will create tourism products that are unique, so it is difficult to be replicated and found elsewhere. Therefore, the uniqueness will become a sustainable competitive advantage factor of its tourism products and making it different from other destinations. Moreover, the sustainable of its tourism sector will lead to multi-multiplying effects in various fields, specifically strengthening economic activities and improving their living standards as the host.

\section{REFERENCES}

Barney, J. B. (1991). Firm Resources and Sustained Competitive Advantage. Journal of Management. Vol. 17, No. 1, Pp. 99-120.

Barney, J. B., and Clark, D.N. (2007). Resource-Based Theory Creating and Sustaining Competitive Advantages. Oxford: Oxford University Press.

Bendesa, I Komang Gede. (2010). Pengembangan Kearifan Lokal sebagai Basis Ekonomi. Central Bereau Statistics of Bali (2012). Bali in Figures.

Bharadwaj, S. G., Varadarajan, P. R., and Fahy, J. (1993). Sustainable Competitive Advantage in Service Industries: A Conceptual Model and Research Propositions. Journal of Marketing. Vol. 57, No. 4, Pp. 83-99. 
Brata, I. B. (2016). Kearifan Budaya Lokal Perekat Identitas Bangsa. Jurnal Bakti Saraswati. Vol. 5, No. 1, Pp. 2088-2149.

Charles, C. H. and Tian, C.S. (2011). Examining the Effects of Tourism Impacts on Resident Quality of Life, Evidence from Rural Midwestern Communities in USA AU- Yu, Chian-Pin (Simon). International Journal of Tourism Sciences. Vol. 11, No. 2, Pp. 137-152.

Collins, J. C., and Porras, J. I. (1996). Building Your Company's Vision. Harvard Business Review. September - Oktober.

Day, G. S. and Wensley, R. (1998). Assessing Advantage: A Framework for Diagnosing Competitive Superiority. Journal of Marketing. Vol. 52, Pp. $1-20$.

Deal, T. E., and Kennedy, A. A. (1982). Corporate Culture: The Rites and Rituals of Corporate Life. Boston: Addison-Wesley Publishing Company.

Freiberg, K., and Freiberg, J. (1996). Nuts!: Southwest Airlines' Crazy Recipe for Business and Personal Success. Michigan: Bard Books.

Geriya, I Wayan. (2011). Antara Aneka Paradoks and Budaya Hibrida (in Jendela Pariwisata Bali: How Lucky is Bali?, initiator: Panudiana Kuhn, compiler/editor: Dwi Yani and Ni Komang Erviani). Second Edition. Bali: Wisnu Press. Pp. 21-40.

Halloway, J. C., and Humpreys, C. (2016). The Business of Tourism. Tenth Edition. Edinburgh, UK: Pearson Education Limited.

Hunt, S. D. (2000). A General Theory of Competition. USA: Sage Publications, Thousand Oaks.

Jensen, M. C. and Meckling, W. H. (1976). Theory of the Firm: Managerial Behaviour, Agency Costs and Ownership Structure. Journal of Financial Economics. Vol. 3, Pp. 305-360.

Kalaiya, A. B. (2015). Tourism as a Development Tool: A Study on Role of Tourism in Economic Development, Employment Generation and Poverty Reduction: Special Focus on Kachchh. International Journal of Advance Research in Computer Science and Management Studies. Vol. 3, No. 7, Pp. 179-197.

Koentjaraningrat. (2005). Kebudayaan, Mentalitas and Pembangunan. Jakarta: Gramedia Pustaka Utama.

Kotter, J. P., and Heskett, J. L. (1992). Corporate Culture and Performance. New York: Free Press.

Peteraf, M. A. (1993). The Cornerstones of Competitive Advantage: A ResourceBased View. Strategic Management Journal. Vol. 14, No. 3, Pp. 179-191.

Peters, T. J., and Waterman, R. H. (1982). In Search of Excellence: Lessons from America's Best-Run Companies. New York: Harper and Row.

Porter, M. E. (1980). Competitive Strategy: Techniques for Analyzing Industries and Competitors. New York: Free Press.

. (1985). Competitive Advantage: Creating and Sustaining Superior Performance. New York: Free Press.

. (1986). Competition in Global Industries. Boston: Harvard Business School Press. . (1996). What is Strategy? Harvard Business Review. Nopember Desember. 
Quick, J. C. (1992). Crafting an Organizational Culture: Herb's Hand at Southwest Airlines. Organizational Dynamics. Vol. 21, No. 2, Pp. 45-56.

Sangalang, I., Darjosanjoto, E. T. S., and Faqih, M. (2011). Understanding Space Based on the Symbol of Batang Garing on Dayak Ngaju House. Pp. 118126.

Schein, E. H. (2004). Organizational Culture and Leadership. Third Edition. San Francisco, CA: Jossey-Bass

Sibarani, R. 2012. Kearifan Lokal: Hakikat, Peran dan Metode Tradisi Lisan. Jakarta: Asosiasi Tradisi Lisan.

Sukawati, Tjokorda Gde Raka. (2014). Merajut Nilai-nilai Kearifan Lokal untuk Membangun Keunggulan Daya Saing Berkelanjutan (Studi Etnografi Pemasaran Pariwisata di Ubud). Disertasi. Program Doktor Ilmu Ekonomi Kekhususan Manajemen, Program Pascasarjana Universitas Brawijaya, Malang.

Tichy, N. (1983). The Essentials of Strategic Change Management. Journal of Business Strategy. Vol. 3, No. 4, Pp. 55-67.

Trout, J. (2001). Differentiate or Die: Survival in Our Era of Killer Competition. New York: John Wiley.

WTTC. (2015). Economic Impact of Travel \& Tourism 2015 Annual Update: Summary. London: World Travel and Tourism Council. 